\title{
Xiao-Ai-Ping, a TCM Injection, Enhances the Antigrowth Effects of Cisplatin on Lewis Lung Cancer Cells through Promoting the Infiltration and Function of $\mathrm{CD8}^{+} \mathrm{T}$ Lymphocytes
}

\author{
Wanshuai Li, ${ }^{1}$ Yang Yang, ${ }^{1}$ Zijun Ouyang, ${ }^{1}$ Qi Zhang, ${ }^{1}$ Lu Wang, ${ }^{1}$ Feifei Tao, \\ Yongqian Shu, ${ }^{2}$ Yanhong Gu, ${ }^{2}$ Qiang $\mathrm{Xu},{ }^{1}$ and Yang Sun $^{1}$ \\ ${ }^{1}$ State Key Laboratory of Pharmaceutical Biotechnology, School of Life Sciences, Nanjing University, 22 Hankou Road, \\ Nanjing 210093, China \\ ${ }^{2}$ Department of Clinical Oncology, The First Affiliated Hospital of Nanjing Medical University, 140 Hanzhong Road, \\ Nanjing 210029, China
}

Correspondence should be addressed to Yanhong Gu; guluer@163.com and Yang Sun; yangsun@nju.edu.cn

Received 27 March 2013; Revised 17 June 2013; Accepted 28 June 2013

Academic Editor: Kevin Chen

Copyright (C) 2013 Wanshuai Li et al. This is an open access article distributed under the Creative Commons Attribution License, which permits unrestricted use, distribution, and reproduction in any medium, provided the original work is properly cited.

\begin{abstract}
Objectives. To investigate how Xiao-Ai-Ping injection, a traditional Chinese medicine and an ancillary drug in tumor treatment, enhances the antitumor effects of cisplatin on Lewis lung cancer (LLC) cells. Methods. LLC-bearing mice were daily intraperitoneally injected with various doses of cisplatin, Xiao-Ai-Ping, or cisplatin plus Xiao-Ai-Ping, respectively. Body weight and tumor volumes were measured every three days. Results. Combination of Xiao-Ai-Ping and cisplatin yielded significantly better antigrowth and proapoptotic effects on LLC xenografts than sole drug treatment did. In addition, we found that Xiao-Ai-Ping triggered the infiltration of $\mathrm{CD}^{+} \mathrm{T}$ cells, a group of cytotoxic T cells, to LLC xenografts. Furthermore, the mRNA levels of interferon- $\gamma($ ifn- $\gamma$ ), perforin-1 (prf-1), and granzyme B $(g z m b)$ in $\mathrm{CD}^{+}$T cells were significantly increased after combination treatment of Xiao-Ai-Ping and cisplatin. In vitro studies showed that Xiao-Ai-Ping markedly upregulated the mRNA levels of ifn- $\gamma$, prf-1, and $g z m b$ in CD8 ${ }^{+}$ $\mathrm{T}$ cells in a concentration-dependent manner, suggesting that Xiao-Ai-Ping augments the function of CD8 ${ }^{+} \mathrm{T}$ cells. Conclusions. Xiao-Ai-Ping promotes the infiltration and function of $\mathrm{CD}^{+} \mathrm{T}$ cells and thus enhances the antigrowth effects of cisplatin on LLC xenografts, which provides new evidence for the combination of Xiao-Ai-Ping and cisplatin in clinic in China.
\end{abstract}

\section{Introduction}

Innate and adaptive immunities play important roles in the development and progression of cancer. It is becoming apparent that tumors can influence the induction of potentially protective responses in a number of ways [1]. Immunotherapies which induce immune responses to tumors have been investigated for over 100 years as an attractive strategy for cancer treatment $[2,3]$. Cancer chemotherapy drugs have long been considered immune suppressive. However, more recent data indicate that some cytotoxic drugs effectively treat cancer in part by facilitating an immune response to the tumor when given at the standard dose and schedule [2]. More recently, two clinical trials of antibodies which target the negative immune checkpoint molecule PD-1 on
$\mathrm{T}$ cells and its ligand B7-H1/PD-L1 on tumor cells were unexpectedly successful, with durable response rates of 20 $25 \%$ in advanced melanoma, renal cell cancer, and nonsmallcell lung cancer (NSCLC) $[2,4,5]$, suggesting the critical role of enhancing immunity in cancer therapy. Immunemediated restriction of tumor growth requires synchronization of several interdependent events, including activation of tolerized immune cells $[6,7]$. Effector $\mathrm{CD}^{+} \mathrm{T}$ cells occupy a key position in cancer immunotherapeutic approaches $[6,8]$. $\mathrm{CD}^{+}$cytotoxic $\mathrm{T}$ cells recognize tumor antigens and kill tumor cells essentially though the release of interferon- $\gamma$ $($ IFN- $\gamma)$, perforin, and granzymes [8-11].

Chemotherapy is one of the key tools used in tumor treatment [12-14], and whether chemotherapy drugs promote antitumor immunity is one of the crucial factors that 
determine the effects of the drugs [1,2, 15-17]. Plant-derived natural products play an important role in cancer chemotherapy. Numerous molecules, such as paclitaxel, vincristine, camptothecin, and epipodophyllotoxin, are invaluable contributions of nature to modern medicine [18]. In recent years, interest in using natural products as therapeutic agents for cancer has sharply increased [12, 19-23]. Thus, the quest to search for novel therapeutic compounds or strategies for cancer treatment and management is a never-ending venture.

Marsdenia tenacissima, the stem of Marsdenia tenacissima (Roxb.) Wight et Arn. (Asclepiadaceae Family), is widely grown in the southern provinces of China [12]. More than 40 C-21 steroidal glycosides have been isolated from Marsdenia tenacissima [24], some of which were proved to show cytotoxic activities against cancer cells [25]. Xiao-Ai-Ping injection, a standard $M$. tenacissima extract, is shown to be clinically effective in treatment of NSCLC when combined with chemotherapeutics agents [26-28]. However, the exact mechanism of the combination strategy remains vague. In the present study, we demonstrate that Xiao-Ai-Ping promotes the infiltration and function of $\mathrm{CD}^{+}$cytotoxic T cells and thus enhances the antigrowth effects of cisplatin on mouse Lewis lung cancer cells. Our data provide the molecular theoretical basis for clinical application of Xiao-Ai-Ping injection in patients with NSCLC.

\section{Materials and Methods}

2.1. Cells and Reagents. Lewis lung cancer (LLC) cells were purchased from the Shanghai Institute of Cell Biology (Shanghai, China), maintained in Dulbecco Minimum Essential Medium (DMEM, GIBCO) supplemented with $10 \%$ fetal bovine serum (FBS, GIBCO), $100 \mathrm{U} / \mathrm{mL}$ penicillin, and $100 \mu \mathrm{g} / \mathrm{mL}$ streptomycin and incubated at $37^{\circ} \mathrm{C}$ in a humidified atmosphere containing $5 \% \mathrm{CO}_{2}$ in the air. XiaoAi-Ping injection ( $5 \mathrm{~g}$ crude $/ \mathrm{mL}$ ) was provided by Sanhome Pharmaceutical Co., Ltd (Nanjing, China) and stored at $4^{\circ} \mathrm{C}$. Cisplatin was purchased from Sigma Aldrich Chemical Co. (St. Louis, MO). For in vivo experiments, Xiao-AiPing and cisplatin were diluted in phosphate buffered saline (PBS); for in vitro experiments, Xiao-Ai-Ping was diluted in fresh media. Phospho-Akt (Thr 308) (\#2965) antibody was purchased from Cell Signaling Technology (Beverly, MA). PCNA (\#sc-7907), and GADD153/CHOP (\#sc-793) antibodies were purchased from Santa Cruz Biotechnology (Santa Cruz, CA). Granzyme B antibody (\#6632-1) was purchased from Epitomics (Burlingame, CA). All other chemicals were purchased from Sigma Aldrich Chemical Co. (St. Louis, MO).

2.2. Animals. C57BL/6J mice (6 to 8 weeks old) were purchased from the Shanghai Laboratory Animal Center (Shanghai, China). Briefly, mice were fed with free access to pellet food and water in plastic cages at $21 \pm 2^{\circ} \mathrm{C}$ and kept on a 12-hour light-dark cycle. Animal welfare and experimental procedures were carried out strictly in accordance with the Guide for the Care and Use of Laboratory Animals (The Ministry of Science and Technology of China, 2006) and the related ethical regulations of our university. All efforts were made to minimize animals' suffering and to reduce the number of animals used.

2.3. RNA Extraction, Reverse Transcription Polymerase Chain Reaction (RT-PCR), and Quantitative PCR (Q-PCR) Analysis. Total RNA extraction and RT-PCR were performed as published before [29]. Briefly, cells were collected and lysed in Trizol (Invitrogen). One $\mu$ g extracted RNA was used for reverse transcription with Oligo(dT) primers (Takara). For RT-PCR analysis, $1 \mu \mathrm{L} c D N A$ products were used, and the primers were as follows: if $n-\gamma$ Sense $\left(5^{\prime}-3^{\prime}\right)$ : ATGAACGCTACACACTGCATC, Antisense $\left(5^{\prime}-3^{\prime}\right)$ : CCATCCTTTTGCCAGTTCCTC; prf-1 Sense $\left(5^{\prime}-3^{\prime}\right)$ : AGCACAAGTTCGTGCCAGG, Anti-sense $\left(5^{\prime}-3^{\prime}\right)$ : GCGTCTCTCATTAGGGAGTTTTT; $g z m b$ Sense $\left(5^{\prime}-3^{\prime}\right)$ : CCACTCTCGACCCTACATGG, Anti-sense $\left(5^{\prime}-3^{\prime}\right)$ : GGCCCCCAAAGTGACATTTATT; $r n 18 s$ Sense $\left(5^{\prime}-3^{\prime}\right)$ : AGTCCCTGCCCTTTGTACACA, Anti-sense $\left(5^{\prime}-3^{\prime}\right)$ : CGATCCGAGGGCCTCACTA. All primers were purchased from GenScript (Nanjing, China). cDNA amplification was performed for 30 cycles with the following settings: $94^{\circ} \mathrm{C}$ for $5 \mathrm{~min}, 94^{\circ} \mathrm{C}$ for $30 \mathrm{sec}, 58^{\circ} \mathrm{C}$ for $30 \mathrm{sec}$, and $72^{\circ} \mathrm{C}$ for $30 \mathrm{sec}$, and $72^{\circ} \mathrm{C}$ for $10 \mathrm{~min}$. The RTPCR products were electrophoresed on a $2 \%$ agarose gel and visualized by ethidium bromide staining. The Gel Imaging and Documentation DigiDoc-It System (version 1.1.23; UVP, Inc., Upland, CA) was used to scan the gels. $18 \mathrm{~S}$ ribosome RNA (Rn18s) was performed as a loading control. For QPCR analysis, the abundance of gene expression was analyzed with SsoFast EvaGreen Supermix (Bio-Rad) on CFX96 Touch Real-Time PCR Detection System (Bio-Rad) and normalized with rn18s level.

2.4. TUNEL and Immunohistochemistry Staining. TUNEL staining was performed using TUNEL FITC Apoptosis Detection Kit from Vazyme Biotech Co., Ltd (Nanjing, China) according to the manufacturer's protocols. Immunohistochemistry staining was performed using GT Vision III Immunohistochemistry Detection Kit (GK500710) from GeneTech Company Limited (Shanghai, China) according to the manufacturer's protocols. The fluorescent signals were detected with a mercury lamp (Olympus U-RFL-T) and analyzed by Image-Pro Plus 6.0 (Media Cybernetics, Inc. Bethesda, MD, USA).

2.5. In Vivo Tumor Growth Assay. LLC cells were cultured in $100 \mathrm{~mm}$ dishes (Costar) and collected in $50 \mathrm{~mL}$ centrifuge tubes. Then the cells were centrifuged (1000 rpm, $5 \mathrm{~min}$ ) and washed twice with ice-cold PBS. The cells were diluted to $1 \times 10^{6} / \mathrm{mL}$ before injection. $1 \times 10^{6}$ LLC cells (in $0.1 \mathrm{~mL} \mathrm{PBS}$ ) were injected subcutaneously into the right flanks of female C57BL6/J mice (6-8 weeks of age). All mice formed tumors three days after injection. Then mice were distributed into four groups $(n=8)$ according to tumor volumes, and the day was marked as day 0 . Vehicle and indicated doses of drugs were administered to every group respectively every day since day 0 . Tumor length and tumor width were measured with a vernier caliper every three days. Tumor volumes were calculated according to the following formula: $0.5 \times$ tumor 


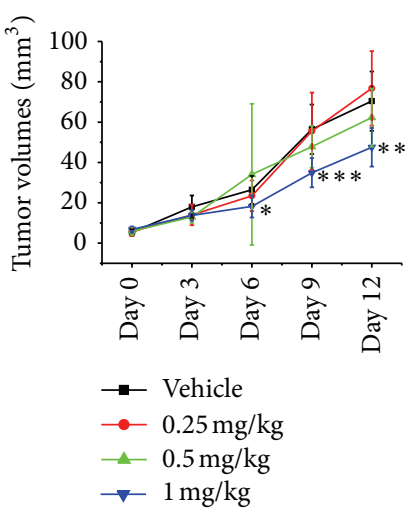

(a)

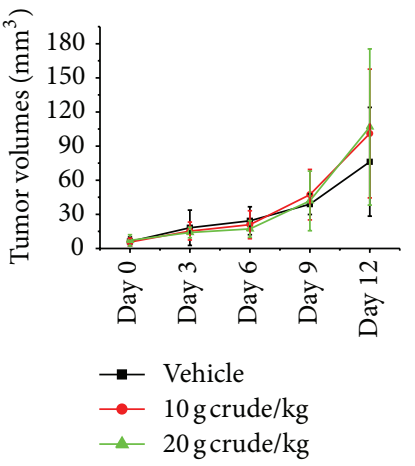

(e)

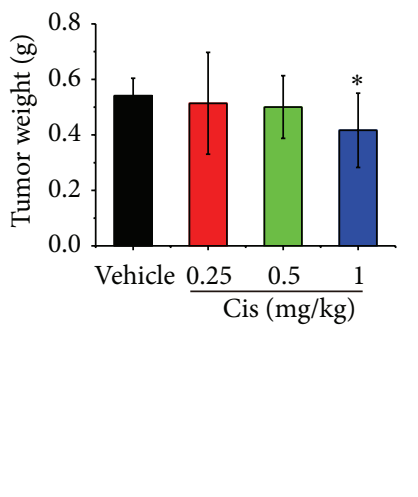

(b)

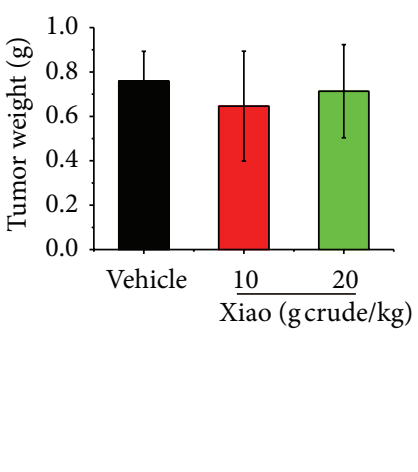

(f)

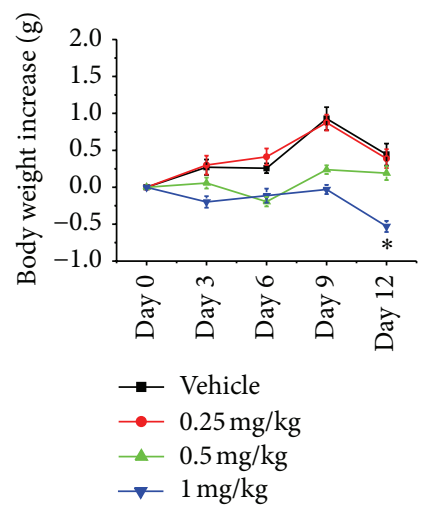

(c)

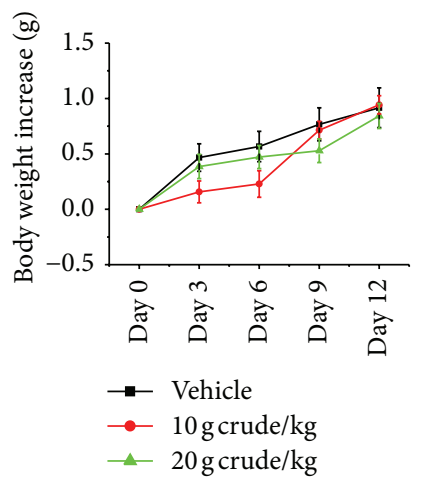

(g)

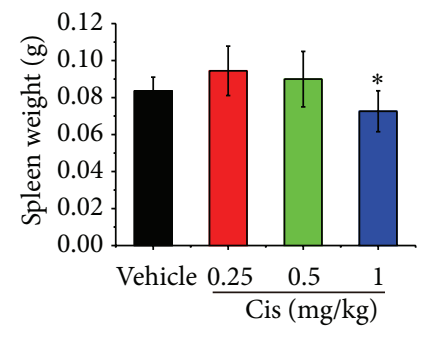

(d)

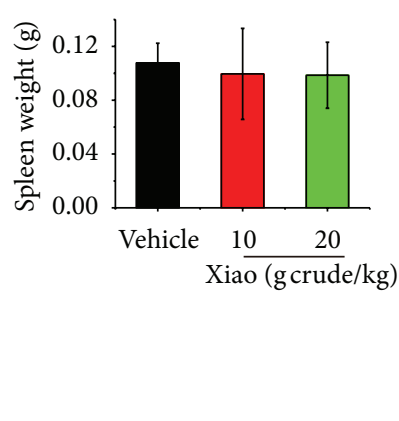

(h)

FIGURE 1: Cisplatin dose-dependently inhibited the growth of LLC xenografts while Xiao-Ai-Ping had little effect. Various doses of cisplatin (Cis, $0.25,0.5,1 \mathrm{mg} / \mathrm{kg}, n=8$ per group) or Xiao-Ai-Ping (Xiao, 10, $20 \mathrm{~g}$ crude $/ \mathrm{kg} n=8$ per group) were daily i.p. injected to LLC-bearing mice, respectively, for 12 days. Body weight and tumor volumes were measured every three days. (a-d) Tumor volumes (a), tumor weight (b), body weight (c), and spleen weight (d) of cisplatin-treated LLC-bearing mice. (e-h) Tumor volumes (e), tumor weight (f), body weight (g), and spleen weight (h) of Xiao-Ai-Ping treated LLC-bearing mice. ${ }^{*} P<0.05,{ }^{* *} P<0.01,{ }^{* * *} P<0.001$ versus vehicle (PBS). LLC, Lewis lung cancer.

length $\times$ tumor width ${ }^{2}$. Tumor weight, body weight, and spleen weight were measured after the mice were euthanized. Tumor sections were infused in formaldehyde solution for immunohistochemistry. The rest sections were shortly frozen in liquid nitrogen and then stored at $-80^{\circ} \mathrm{C}$.

2.6. Preparation of Mouse $C D 8^{+} T$ Cells. Mouse $\mathrm{CD}^{+} \mathrm{T}$ cells were isolated from the lymph nodes with Dynabeads FlowComp Mouse CD8 Kit (11462D, Invitrogen) according to the manufacturer's protocols. Briefly, $1 \mathrm{~mL}\left(1 \times 10^{8}\right)$ cells isolated from the lymph nodes were transferred to a tube and incubated with $50 \mu \mathrm{L}$ FlowComp Mouse CD8 antibody for $10 \mathrm{~min}$ at $4^{\circ} \mathrm{C}$. The cells were resuspended in $2 \mathrm{~mL}$ isolation buffer $\left(\mathrm{Ca}^{2+}\right.$ and $\mathrm{Mg}^{2+}$ free PBS supplemented with $0.1 \%$ BSA and $2 \mathrm{mM}$ EDTA) after being washed once with $4 \mathrm{~mL}$ isolation buffer. Then the suspensions were incubated with $150 \mu \mathrm{L}$ washed FlowComp Dynabeads for $15 \mathrm{~min}$ at $4^{\circ} \mathrm{C}$ under rolling and tilting. Then $2 \mathrm{~mL}$ isolation buffer was added, and the tube was placed in a magnet for $2 \mathrm{~min}$. The supernatant containing CD8 negative cells was carefully removed and discarded, while the tube was still in the magnet. The beadbound $\mathrm{CD}^{+}$cells were washed once with isolation buffer. Then $\mathrm{CD}^{+}$cells were released from the beads with release buffer (modified biotin in $0.1 \%$ BSA and 2 mM EDTA). The cells were kept at $4^{\circ} \mathrm{C}$ until further use.

2.7. Statistical Analysis. Data are expressed as means \pm SD. One way ANOVA was used to test for differences among more than two groups. The Student's $t$-test was used to evaluate the difference between two groups. $P<0.05$ was considered to be significant.

\section{Results}

3.1. Cisplatin Dose-Dependently Inhibited the Growth of LLC Xenografts While Xiao-Ai-Ping Had Little Effect on the Growth of LLC Xenografts. To examine the respective effects of cisplatin and Xiao-Ai-Ping on the growth of LLC xenografts, various doses of cisplatin $(0,0.25,0.5,1 \mathrm{mg} / \mathrm{kg})$ and XiaoAi-Ping $(0,10,20 \mathrm{~g}$ crude/ $\mathrm{kg}$, the doses were determined according to the clinical dosage of Xiao-Ai-Ping injection) were, respectively, intraperitoneally (i.p.) injected to the LLCbearing mice for 12 days. One $\mathrm{mg} / \mathrm{kg}$ cisplatin led to a significant decrease in the growth and weight of LLC xenografts (Figures 1(a) and 1(b)), while $20 \mathrm{~g}$ crude/kg Xiao-Ai-Ping only had little effects (Figures 1(e) and 1(f)). It was also shown that 


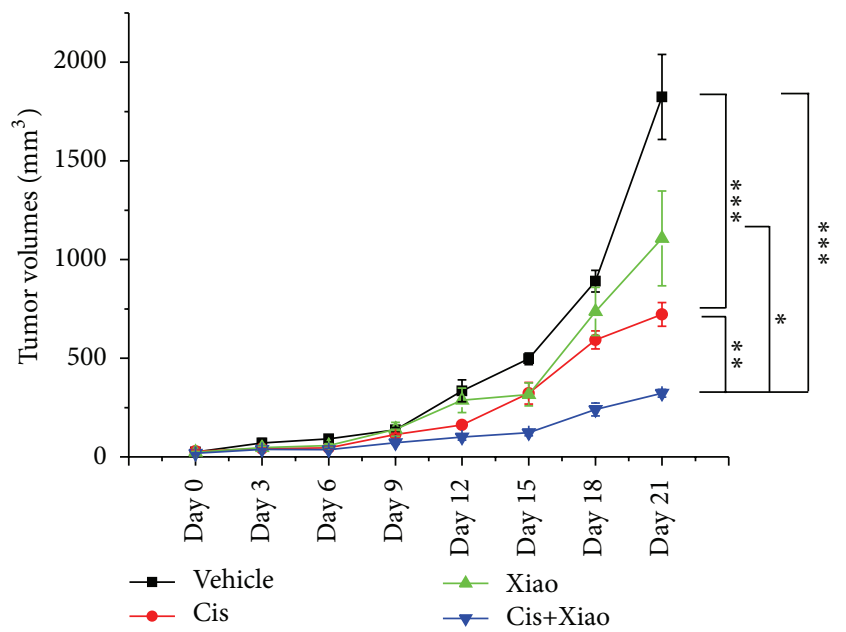

(a)

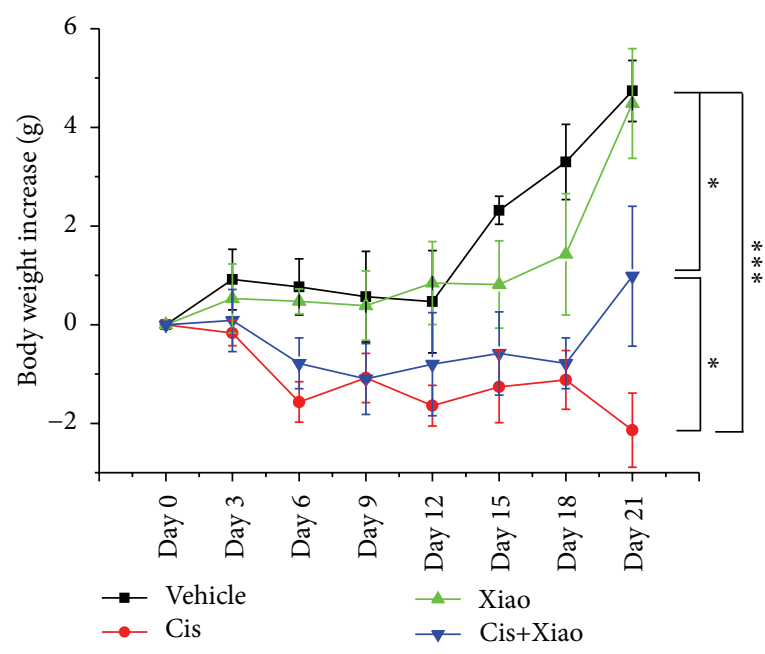

(c)

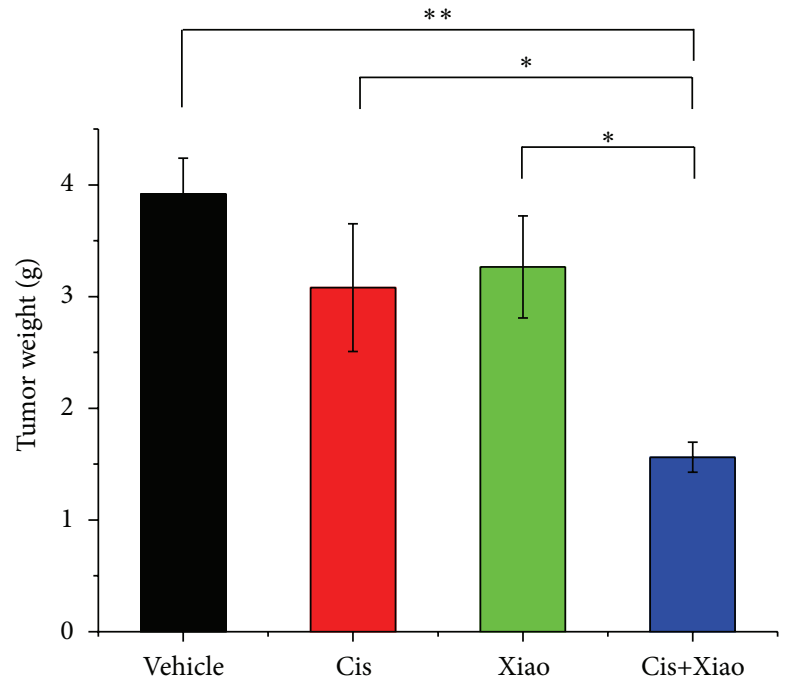

(b)

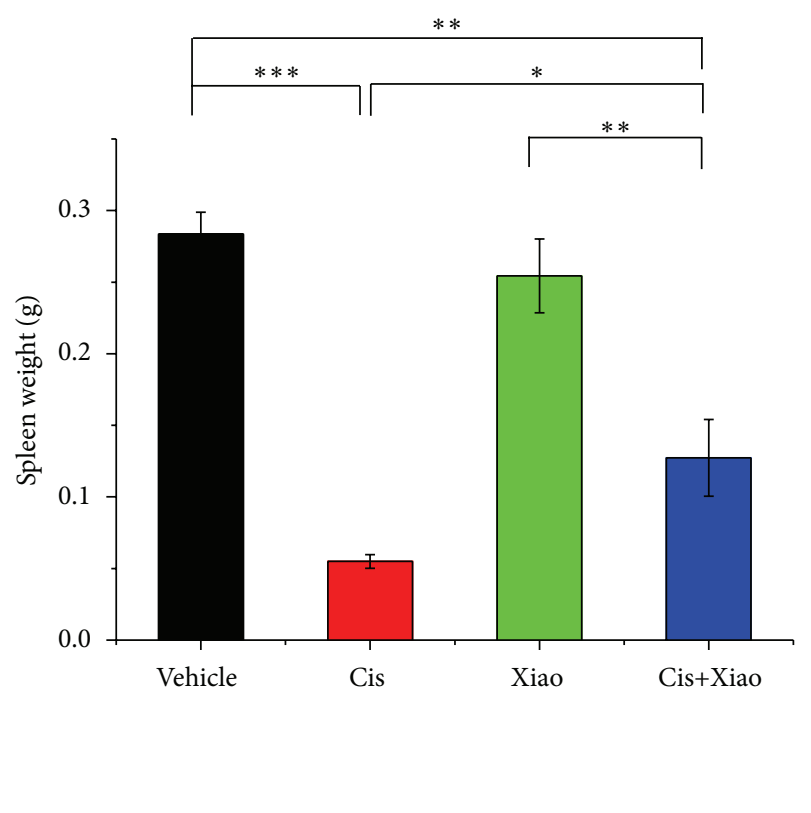

(d)

FIGURE 2: Combination of cisplatin with Xiao-Ai-Ping had significantly better effects than cisplatin. PBS (Vehicle, $n=8), 1 \mathrm{mg} / \mathrm{kg}$ cisplatin (Cis, $n=8$ ), $20 \mathrm{~g}$ crude $/ \mathrm{kg}$ Xiao-Ai-Ping (Xiao, $n=8$ ), and $1 \mathrm{mg} / \mathrm{kg}$ cisplatin plus $20 \mathrm{~g}$ crude $/ \mathrm{kg}$ Xiao-Ai-Ping (Cis+Xiao, $n=8)$ were daily i.p. injected for 21 days, respectively. (a) Tumor volumes. (b) Tumor weight. (c) Body weight. (d) Spleen weight. ${ }^{*} P<0.05$, ${ }^{* *} P<0.01$, ${ }^{* * *} P<0.001$.

$1 \mathrm{mg} / \mathrm{kg}$ cisplatin significantly decreased the body weight and spleen weight of LLC-bearing mice (Figures 1(c) and 1(d)), while $20 \mathrm{~g}$ crude/kg Xiao-Ai-Ping had no influences (Figures $1(\mathrm{~g})$ and $1(\mathrm{~h})$ ). Considering the clinical dosage of Xiao-AiPing injection, we use $20 \mathrm{~g}$ crude/kg Xiao-Ai-Ping combined with $1 \mathrm{mg} / \mathrm{kg}$ cisplatin in the following study.

3.2. Xiao-Ai-Ping Promoted the Antigrowth Effect of Cisplatin on LLC Xenograft. Vehicle (PBS, $n=8)$, cisplatin $(1 \mathrm{mg} / \mathrm{kg}$, $n=8)$, Xiao-Ai-Ping (20 g crude/kg, $n=8)$, and cisplatin plus Xiao-Ai-Ping $(1 \mathrm{mg} / \mathrm{kg}$ cisplatin plus $20 \mathrm{~g}$ crude $/ \mathrm{kg}$ XiaoAi-Ping, $n=8$ ) were i.p. injected into LLC-bearing mice for 21 days. Cisplatin $(1 \mathrm{mg} / \mathrm{kg})$ significantly reduced the volumes $(P<0.001$, Figure $2(\mathrm{a})$, the red line) and weight $(P<0.05$, Figure $2(\mathrm{~b})$, the red column) of LLC xenografts, while $20 \mathrm{~g}$ crude/ $\mathrm{kg}$ Xiao-Ai-Ping only had slight effects (no significant difference versus vehicle group, Figure 2(a), the green line and Figure 2(b), the green column). Interestingly, 

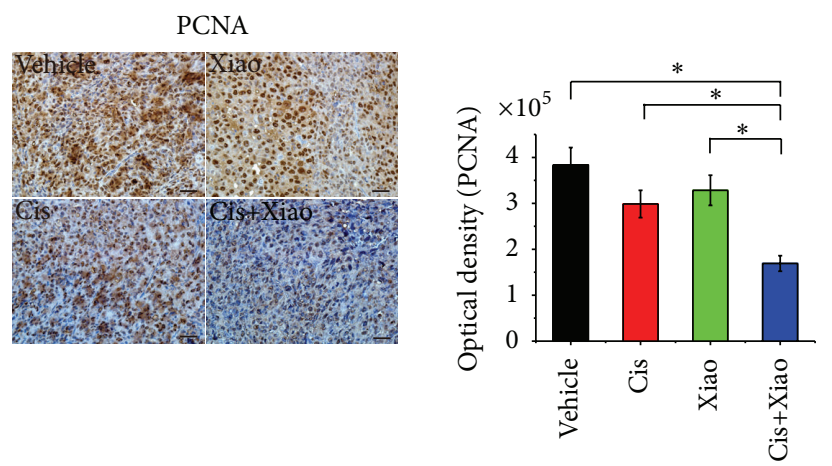

(a)
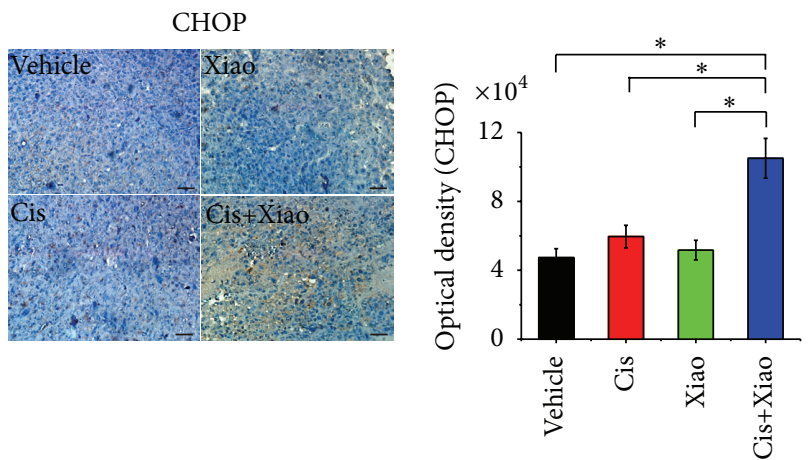

(c)
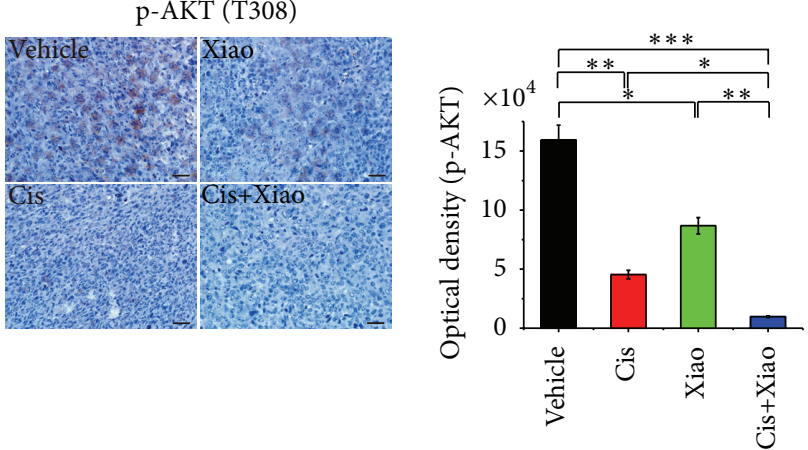

(b)
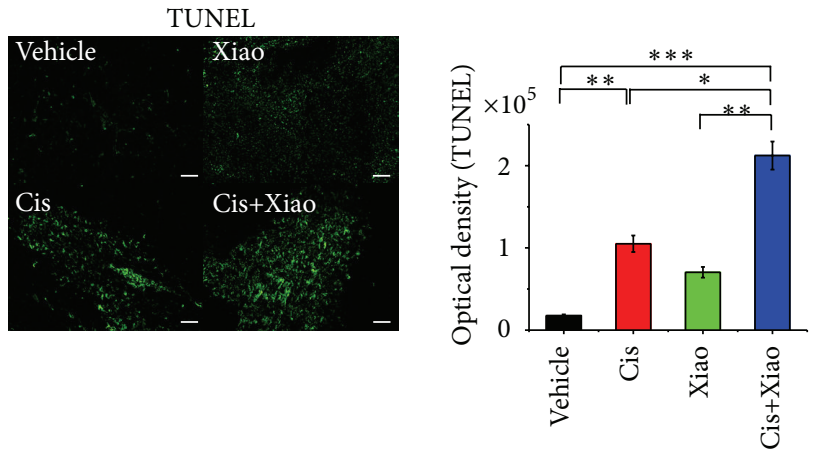

(d)

Figure 3: Xiao-Ai-Ping promotes the antigrowth and proapoptotic effects of cisplatin on LLC xenografts. PBS (Vehicle, $n=8), 1 \mathrm{mg} / \mathrm{kg}$ cisplatin (Cis, $n=8$ ), $20 \mathrm{~g}$ crude/kg Xiao-Ai-Ping (Xiao, $n=8$ ), and $1 \mathrm{mg} / \mathrm{kg}$ cisplatin plus $20 \mathrm{~g}$ crude/kg Xiao-Ai-Ping (Cis+Xiao, $n=8)$ were daily injected for 21 days, respectively. Tumor sections were infused in formaldehyde solution for immunohistochemistry. (a) Expression of PCNA (left panel) and average optical density of five samples (right panel). (b) Expression of phospho-Akt (left panel) and average optical density of five samples (right panel). (c) Expression of CHOP (left panel) and average optical density of five samples (right panel). (d) TUNEL staining of tumor sections (left panel) and average optical density of five samples (right panel). Images were representative of eight samples per group, and quantitation data were average of eight samples. Scale bars, $10 \mu \mathrm{m} .{ }^{*} P<0.05,{ }^{* *} P<0.01,{ }^{* * *} P<0.001$.

combination of $1 \mathrm{mg} / \mathrm{kg}$ cisplatin with $20 \mathrm{~g}$ crude $/ \mathrm{kg}$ XiaoAi-Ping had significantly better effects than $1 \mathrm{mg} / \mathrm{kg}$ cisplatin (Figure 2(a), the blue line and Figure 2(b), the blue column). It should be noted that $1 \mathrm{mg} / \mathrm{kg}$ cisplatin significantly decreased the body weight $(P<0.001$, Figure $2(\mathrm{c})$, the red line) and spleen weight $(P<0.001$, Figure $2(\mathrm{~d})$, the red column) of LLC-bearing mice. However, Xiao-Ai-Ping, at the dose of $20 \mathrm{~g}$ crude $/ \mathrm{kg}$, had no effects on the body weight (Figure 2(c), the green line and Figure 2(d), the green column) or spleen weight (Figure 2(d), the green column) of LLC- bearing mice. Notably, combination of cisplatin with Xiao-Ai-Ping remarkably attenuated the toxicity of cisplatin on the body weight (Figure 2(c), the blue line) and spleen weight (Figure 2(d), the blue column). These results imply that Xiao-Ai-Ping enhances the antigrowth effects of cisplatin on LLC xenografts and attenuates the side effects of cisplatin.

\subsection{Xiao-Ai-Ping Enhanced the Proapoptotic Effect of Cisplatin} on LLC Xenografts. Anti-growth and proapoptotic effects of chemotherapy drugs are crucial for cancer treatment $[30,31]$. Here we detected the levels of several markers for tumor growth and apoptosis. Proliferating cell nuclear antigen (PCNA) and phosphorylation of protein kinase B
(Akt) are markers for tumor growth [32, 33]. DNA damageinducible transcript 3, also known as C/EBP homologous protein $(\mathrm{CHOP})$, is a key marker for tumor apoptosis $[34,35]$. Compared with sole drug treatment, $1 \mathrm{mg} / \mathrm{kg}$ cisplatin combined with $20 \mathrm{~g}$ crude/kg Xiao-Ai-Ping significantly decreased the protein levels of PCNA (Figure 3(a)) and phosphorylated Akt (Thr 308) (Figure 3(b)) in LLC xenografts. Meanwhile, the protein level of $\mathrm{CHOP}$ was significantly increased (Figure 3(c)). TUNEL staining implied that $1 \mathrm{mg} / \mathrm{kg}$ cisplatin combined with $20 \mathrm{~g}$ crude $/ \mathrm{kg}$ Xiao-AiPing induced significantly more apoptosis than sole drug treatment did (Figure 3(d)).

3.4. Xiao-Ai-Ping Increased the Infiltration and Function of $\mathrm{CD}^{+} \mathrm{T}$ Cells. $\mathrm{CD}^{+} \mathrm{T}$ cells play an important role in antitumor immunity $[6,36,37]$. Release of interferon- $\gamma$ (IFN$\gamma)$, perforin, and granzymes is one crucial way of $\mathrm{CD}^{+}$ cytotoxic $T$ cells to kill tumor cells $[6,37,38]$. In the following study, we found that combination of $1 \mathrm{mg} / \mathrm{kg}$ cisplatin with $20 \mathrm{~g}$ crude/kg Xiao-Ai-Ping significantly increased the infiltration of $\mathrm{CD}^{+} \mathrm{T}$ cells to LLC xenografts $(P<0.01$, Figure 4(a) and Figure 4(b)). Meanwhile, mRNA and protein level of granzyme B $(P<0.05$, Figures $4(\mathrm{c})-4(\mathrm{e}))$, and 


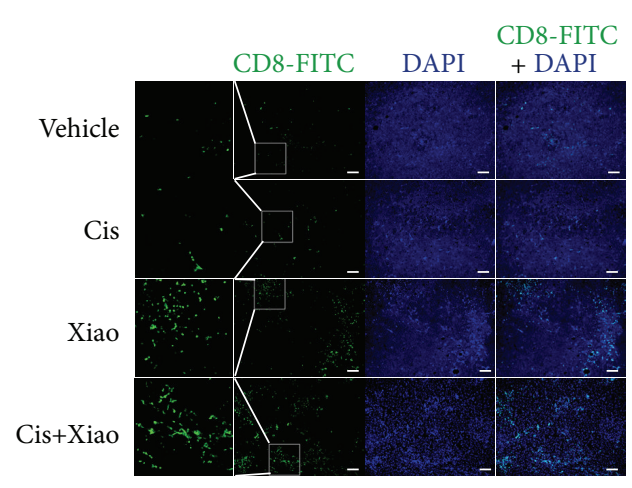

(a)

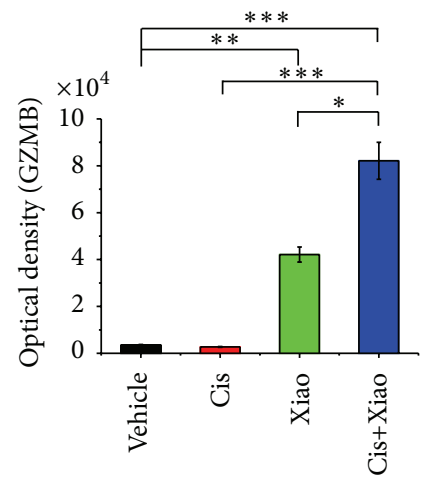

(d)

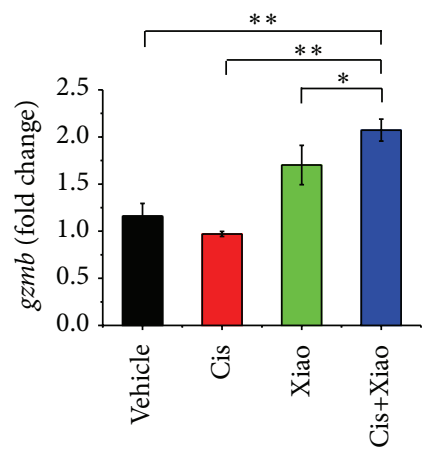

(e)

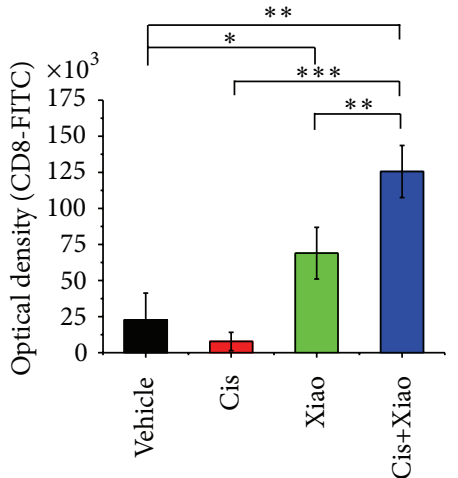

(b)

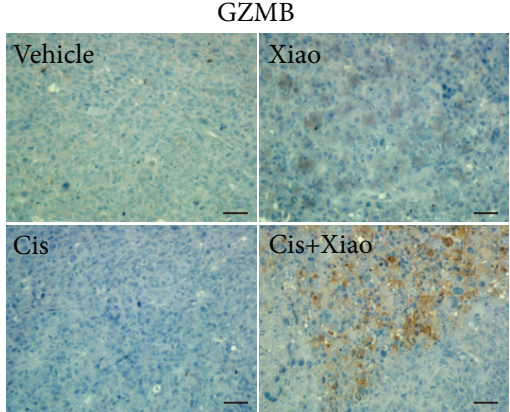

(c)

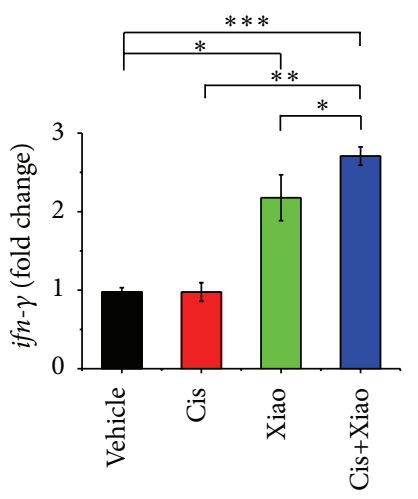

(f)

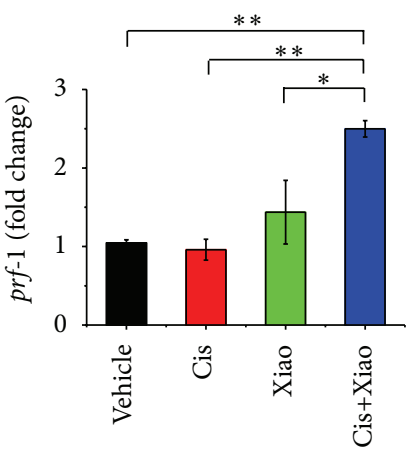

(g)

FIGURE 4: Xiao-Ai-Ping enhances infiltration and functions of CD8 ${ }^{+}$T cells in LLC xenografts. PBS (Vehicle, $\left.n=8\right), 1 \mathrm{mg} / \mathrm{kg}$ cisplatin (Cis, $n=8$ ), $20 \mathrm{~g}$ crude/kg Xiao-Ai-Ping (Xiao, $n=8$ ), and $1 \mathrm{mg} / \mathrm{kg}$ cisplatin plus $20 \mathrm{~g}$ crude $/ \mathrm{kg}$ Xiao-Ai-Ping (Cis+Xiao, $n=8)$ were daily i.p. injected for 21 days, respectively. Tumor sections were infused in formaldehyde solution for immunofluorescence or shortly frozen in liquid nitrogen for RNA extraction. ( $a$ and b) (a) Immunofluorescence of tumor sections. Green, CD8-FITC (Invitrogen); blue, DAPI (4,6diamidino-2-phenylindole, Sigma). Scale bars, $20 \mu \mathrm{m}$. Images were representative of eight samples per group. (b) Quantitation of CD8-FITC (average of eight samples per group). (c and d) Immunohistochemisty stain of tumor sections. (c) Representative images of eight samples per group. Scale bars, $10 \mu \mathrm{m}$. (d) Quantitation of GZMB (average of eight samples per group). (e-g) The mRNA levels of $g z m b$ (e), ifn- $\gamma$ (f), and $\operatorname{prf}-1$ (g) were analyzed by Q-PCR and normalized with $r n 18 s .{ }^{*} P<0.05,{ }^{* *} P<0.01,{ }^{* * *} P<0.001$.

mRNA levels of ifn- $\gamma$ (Figure 4(f)) and prf-1 (Figure 4(g)) were significantly increased in cisplatin-plus-Xiao-Ai-Pingtreated xenografts, compared to cisplatin-treated or Xiao-AiPing-treated xenografts.

In the in vitro study, $\mathrm{CD}^{+} \mathrm{T}$ cells were isolated from mouse lymph nodes and incubated with various concentrations $(0,12.5,25$, and $50 \mathrm{mg}$ crude/mL) of Xiao-Ai-Ping for $12 \mathrm{~h}$. Results showed that Xiao-Ai-Ping significantly enhanced the mRNA levels of ifn- $\gamma, p r f-1$, and gzmb in a concentration-dependent manner (Figure 5). Considering that herbal extracts tend to be contaminated with lipopoly saccharide (LPS) during preparation, we detected the concentration of LPS in Xiao-Ai-Ping injection with Tachypleus Amebocyte Lysate kit (Chinese Horseshoe Crab Reagent manufactory Co., Ltd., Xiamen, China). No LPS contamination was detected in Xiao-Ai-Ping injection. Therefore, the changes in mRNA levels of ifn- $\gamma, \operatorname{prf}-1$, and $g z m b$ were not caused by contaminated LPS.

In conclusion, as described in Figure 6, these results suggest that Xiao-Ai-Ping promotes the infiltration of $\mathrm{CD} 8^{+}$ cytotoxic $\mathrm{T}$ cells to the tumor site and enhances the expressions of IFN- $\gamma$, perforin, and granzyme B from $\mathrm{CD}^{+}{ }^{+}$cells and thus facilitates the antigrowth and proapoptotic effects of cisplatin.

\section{Discussion}

Chemotherapy combined with immunotherapy has been an effective strategy for cancer treatment $[1-3,6]$. In our present study, we demonstrated that traditional Chinese medicine Xiao-Ai-Ping injection enhanced the anti-growth and proapoptotic effects of cisplatin on LLC xenografts through promoting the infiltration and function of $\mathrm{CD}^{+}$cytotoxic $\mathrm{T}$ cells.

It should be noted that Xiao-Ai-Ping only had slight effects on growth and apoptosis of LLC xenografts. However, combination of cisplatin with Xiao-Ai-Ping induced significantly more apoptosis of LLC xenografts than cisplatin alone did. To our interest, the effect of $1 \mathrm{mg} / \mathrm{kg}$ cisplatin alone was not satisfactory, and Xiao-Ai-Ping alone only had 


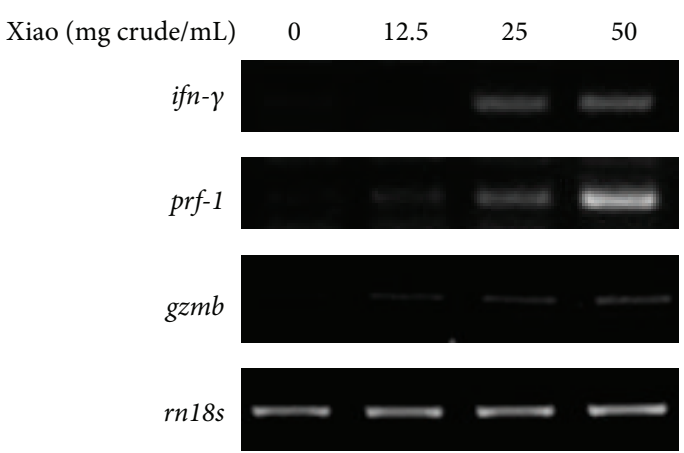

(a)

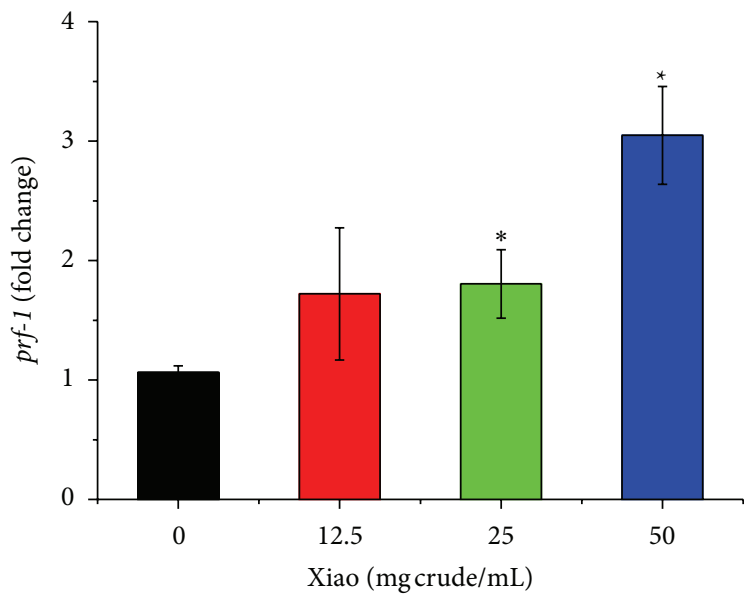

(c)

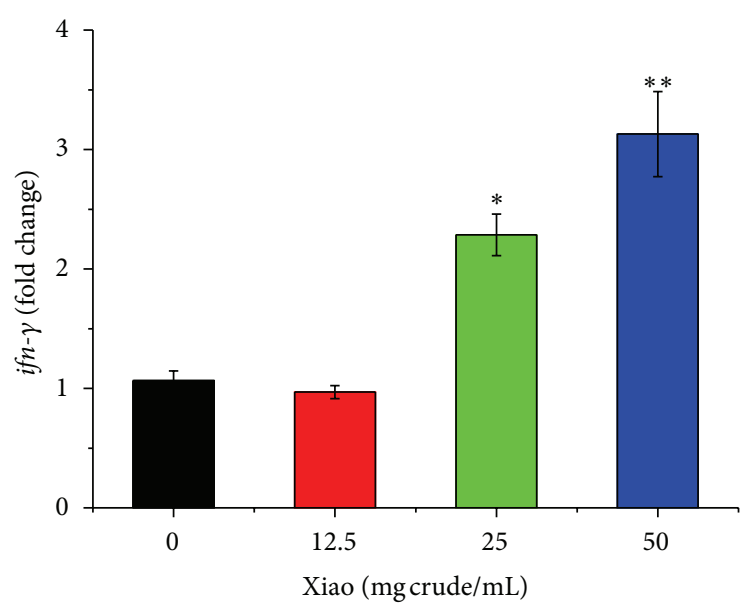

(b)

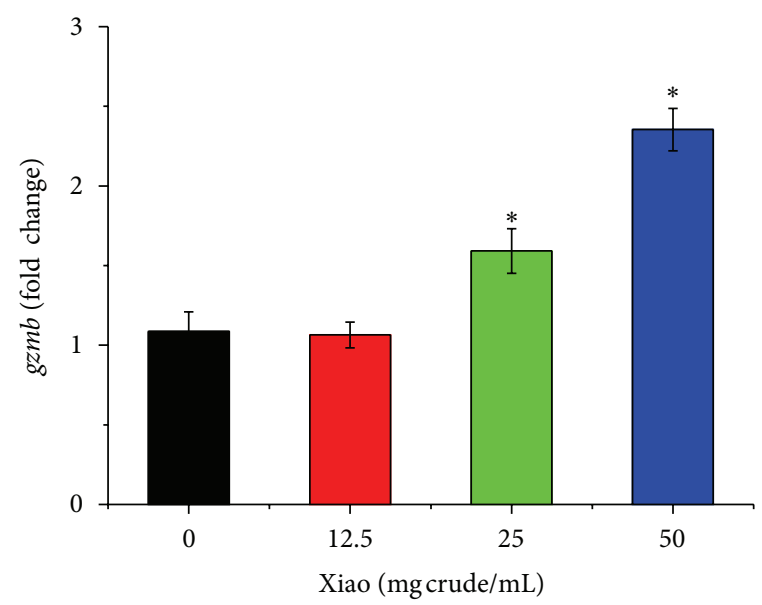

(d)

Figure 5: Xiao-Ai-Ping increases the mRNA expressions of ifn- $\gamma$, prf-1, and $g z m b$ of CD8 ${ }^{+} \mathrm{T}$ cells in vitro. CD8 ${ }^{+} \mathrm{T}$ cells isolated from the lymph nodes of female C57BL6/J mice were incubated with various concentrations of Xiao-Ai-Ping (Xiao) for $12 \mathrm{~h}$. Total RNA from the cells were extracted. (a) RT-PCR analysis of $i f n-\gamma, p r f-1$, and $g z m b$. Rn18s was performed as a loading control. All the experiments were repeated at least three times, and one representative result was shown. (b-d) mRNA expression of ifn- $\gamma$ (b), prf-1 (c), and gzmb (d), normalized with rn18s. ${ }^{*} P<0.05,{ }^{* *} P<0.01$ versus $0 \mathrm{mg}$ crude/mL Xiao-Ai-Ping. All the experiments were repeated at least three times.

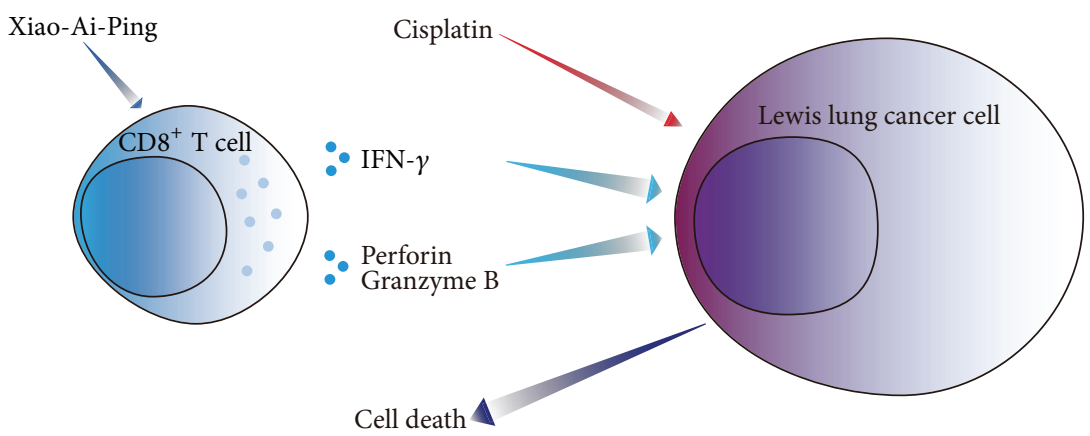

FIGURE 6: Overview of mechanism of synergetic anticancer effect of combination of cisplatin with Xiao-Ai-Ping on Lewis lung cancer cells. Xiao-Ai-Ping promotes the release of IFN- $\gamma$, perforin, and granzyme B from $\mathrm{CD}^{+} \mathrm{T}$ cells, promotes the functions of $\mathrm{CD} 8^{+}$cytotoxic $\mathrm{T}$ cells and thus enhances the antigrowth and proapoptotic effects of cisplatin on LLC cells. 
slight antitumor effects. So we wondered why combination of cisplatin with Xiao-Ai-Ping had such great synergetic antitumor effects.

In the in vitro study, we found that Xiao-Ai-Ping dosedependently enhanced the function of $\mathrm{CD}^{+} \mathrm{T}$ cells, as the mRNA levels of if $n-\gamma, p r f-1$, and $g z m b$ of T cells were increased by the treatment of Xiao-Ai-Ping. Moreover, Xiao-Ai-Ping remarkably increased the infiltration and function of $\mathrm{CD} 8^{+} \mathrm{T}$ cells in LLC xenografts. Meanwhile, combination of cisplatin with Xiao-Ai-Ping induced much more infiltration of $\mathrm{CD}^{+}$ $\mathrm{T}$ cells in LLC xenografts. Cisplatin did not promote either infiltration or function of CD ${ }^{+} \mathrm{T}$ cells, despite its strong antitumor effect. These results suggest that cisplatin and XiaoAi-Ping might play different roles against cancer. Cisplatin induced apoptosis of LLC cells and directly killed cancer cells, while Xiao-Ai-Ping regulated the immune system of LLCbearing mice and promoted anticancer immune response. Notably, low dose of cisplatin $(1 \mathrm{mg} / \mathrm{kg})$ only induced limited apoptosis of LLC cells but greatly suppressed the immune system of LLC-bearing mice, which restricted its anticancer effect and clinical dosage. Most importantly, when cisplatin was combined with Xiao-Ai-Ping, the weights of body and spleen from LLC-bearing mice were no longer decreased so drastically as cisplatin sole group. In addition, more infiltration and function of $\mathrm{CD}^{+} \mathrm{T}$ cells were seen in the combination group than in the sole one. From the data of Figure 2, we know that Xiao-Ai-Ping alone had slight anticancer effect on LLC xenografts. In the process of killing LLC cells, cisplatin exerts a dominant role, while Xiao-AiPing plays a supportive function. Xiao-Ai-Ping's auxiliary role is essential to achieve better anti-LLC effects of cisplatin, since cisplatin usually impairs the anti-tumor immunity in tumor-bearing mice. Xiao-Ai-Ping alone hardly kills LLC cells since Xiao-Ai-Ping has little cytotoxic effects, although Xiao-Ai-Ping increases the infiltration and function of $\mathrm{CD}^{+}$ $\mathrm{T}$ cells. These results collectively suggest that Xiao-Ai-Ping promotes the anticancer effect of cisplatin by enhancing anticancer immunity in mice.

\section{Conclusions}

The current study demonstrates for the first time that XiaoAi-Ping promotes the infiltration and function of $\mathrm{CD}^{+}$ cytotoxic T cells and modulates the immune system in tumorbearing mice and thus enhances the anticancer effect of cisplatin. The present study gives a theoretical support for the clinical use of Xiao-Ai-Ping injection in patients with NSCLC.

\section{Authors' Contribution}

W. Li, Y. Gu, Y. Sun, and Q. Xu conceived and designed the experiments. W. Li, Y. Yang, and Z. Ouyang performed the experiments. W. Li analyzed the data. L. Wang, Q. Zhang, F. Tao, Y. Shu, and Y. Gu contributed reagents/materials/ analysis tools. W. Li, Y. Sun, and Q. Xu wrote the paper. All authors revised, read, and approved the paper.

\section{Conflict of Interests}

No potential conflict of interests was disclosed.

\section{Acknowledgments}

This work was supported by National Natural Science Foundation of China (nos. 90913023, 91229109, 81101563, and 81273528), National Science and Technology Major Project (no. 2012ZX09304-001), and Jiangsu Province Clinical Science and Technology Project (Clinical Research Center, BL2012008).

\section{References}

[1] G. A. Foulds, J. Radons, M. Kreuzer, G. Multhoff, and A. G. Pockley, "Influence of tumors on protective anti-tumor immunity and the effects of irradiation," Frontiers in Oncology, vol. 3, article 14, 2013.

[2] G. Chen and L. A. Emens, "Chemoimmunotherapy: reengineering tumor immunity," Cancer Immunology, Immunotherapy, vol. 62, no. 2, pp. 203-216, 2013.

[3] I. Mellman, G. Coukos, and G. Dranoff, "Cancer immunotherapy comes of age," Nature, vol. 480, no. 7378, pp. 480-489, 2011.

[4] S. L. Topalian, F. S. Hodi, J. R. Brahmer et al., "Safety, activity, and immune correlates of anti-PD-1 antibody in cancer," The New England Journal of Medicine, vol. 366, no. 26, pp. 24432454, 2012.

[5] J. R. Brahmer, S. S. Tykodi, L. Q. Chow et al., "Safety and activity of anti-PD-L1 antibody in patients with advanced cancer," The New England Journal of Medicine, vol. 366, no. 26, pp. 24552465, 2012.

[6] A. Mallick, S. Barik, K. K. Goswami et al., "Neem leaf glycoprotein activates $\mathrm{CD}^{+} \mathrm{T}$ cells to promote therapeutic anti-tumor immunity inhibiting the growth of mouse sarcoma," PLoS ONE, vol. 8, no. 1, Article ID e47434, 2013.

[7] E. M. Higham, C. Shen, K. D. Wittrup, and J. Chen, "Cutting edge: delay and reversal of $\mathrm{T}$ cell tolerance by intratumoral injection of antigen-loaded dendritic cells in an autochthonous tumor model," Journal of Immunology, vol. 184, no. 11, pp. 59545958, 2010.

[8] R. Wu, M. A. Forget, J. Chacon et al., "Adoptive T-cell therapy using autologous tumor-infiltrating lymphocytes for metastatic melanoma: current status and future outlook," Cancer Journal, vol. 18, no. 2, pp. 160-175, 2012.

[9] J. I. Sin, J. B. Park, I. H. Lee et al., "Intratumoral electroporation of IL-12 cDNA eradicates established melanomas by Trp2180188-specific $\mathrm{CD}^{+}$CTLs in a perforin/granzyme-mediated and IFN- $\gamma$-dependent manner: application of Trp2180-188 peptides," Cancer Immunology, Immunotherapy, vol. 61, no. 10, pp. 1671-1682, 2012.

[10] W. F. Cheng, C. F. Hung, K. Y. Lin et al., "CD8 ${ }^{+}$T cells, NK cells and IFN- $\gamma$ are important for control of tumor with downregulated MHC class I expression by DNA vaccination," Gene Therapy, vol. 10, no. 16, pp. 1311-1320, 2003.

[11] J. A. Hollenbaugh and R. W. Dutton, "IFN- $\gamma$ or CD8 T cell expansion, migration, and leads to apoptosis of cells of a solid tumor," Journal of Immunology, vol. 177, no. 5, pp. 3004-3011, 2006.

[12] Z. Huang, H. Lin, Y. Wang, Z. Cao, W. Lin, and Q. Chen, "Studies on the anti-angiogenic effect of Marsdenia tenacissima 
extract in vitro and in vivo," Oncology Letters, vol. 5, no. 3, pp. 917-922, 2013.

[13] E. M. Saleh, R. A. El-Awady, and N. Anis, "Predictive markers for the response to 5-fluorouracil therapy in cancer cells: constant-field gel electrophoresis as a tool for prediction of response to 5-fluorouracil-based chemotherapy," Oncology Letters, vol. 5, no. 1, pp. 321-327, 2013.

[14] T. Watanabe, "Evidence produced in Japan: tegafur-based preparations for postoperative chemotherapy in breast cancer," Breast Cancer, 2013.

[15] T. H. Kang, C. P. Mao, S. Y. Lee et al., "Chemotherapy acts as an adjuvant to convert the tumor microenvironment into a highly permissive state for vaccination-induced antitumor immunity," Cancer Research, vol. 73, no. 8, pp. 2493-2504, 2013.

[16] G. Murugaiyan and B. Saha, "IL-27 in tumor immunity and immunotherapy," Trends in Molecular Medicine, vol. 19, no. 2, pp. 108-116, 2013.

[17] C. Pasero and D. Olive, "Interfering with coinhibitory molecules: BTLA/HVEM as new targets to enhance anti-tumor immunity," Immunology Letters, vol. 151, no. 1-2, pp. 71-75, 2013.

[18] R. G. Mehta, G. Murillo, R. Naithani, and X. Peng, "Cancer chemoprevention by natural products: how far have we come?" Pharmaceutical Research, vol. 27, no. 6, pp. 950-961, 2010.

[19] H. F. Ji, X. J. Li, and H. Y. Zhang, "Natural products and drug discovery: can thousands of years of ancient medical knowledge lead us to new and powerful drug combinations in the fight against cancer and dementia?" EMBO Reports, vol. 10, no. 3, pp. 194-200, 2009.

[20] A. I. Gray, J. O. Igoli, and R. Edrada-Ebel, "Natural products isolation in modern drug discovery programs," Methods in Molecular Biology, vol. 864, pp. 515-534, 2012.

[21] S. Mondal, S. Bandyopadhyay, M. K. Ghosh, S. Mukhopadhyay, S. Roy, and C. Mandal, "Natural products: promising resources for cancer drug discovery," Anti-Cancer Agents in Medicinal Chemistry, vol. 12, no. 1, pp. 49-75, 2012.

[22] Y. Tu and B. Yan, "High-throughput fractionation of natural products for drug discovery," Methods in Molecular Biology, vol. 918, pp. 117-126, 2012.

[23] N. I. Vasilevich, R. V. Kombarov, D. V. Genis, and M. A. Kirpichenok, "Lessons from natural products chemistry can offer novel approaches for synthetic chemistry in drug discovery," Journal of Medicinal Chemistry, vol. 55, no. 16, pp. 7003-7009, 2012.

[24] H. Zhang, A. M. Tan, A. Y. Zhang, R. Chen, S. Yang, and X. Huang, "Five new C21 steroidal glycosides from the stems of Marsdenia tenacissima," Steroids, vol. 75, no. 2, pp. 176-183, 2010.

[25] S. X. Qiu, S. Q. Luo, L. Z. Lin, and G. A. Cordell, "Further polyoxypregnanes from Marsdenia tenacissima," Phytochemistry, vol. 41, no. 5, pp. 1385-1388, 1996.

[26] W. Y. Wang, Y. Zhou, X. J. Zhang, T. H. Gao, Z. F. Luo, and M. Y. Liu, "A random study of xiaoaiping injection combined with chemotherapy on the treatment of advanced non-small cell lung cancer," Chinese Clinical Oncology, vol. 14, pp. 936-938, 2009 (Chinese).

[27] Z. Q. Huang, H. Tan, C. Y. Wang et al., "Clinical research of combined xiaoaiping injection with chemotherapy on advanced non-small cell lung cancer," Chinese Clinical Oncology, vol. 12, pp. 97-99, 2007 (Chinese).

[28] W. Ken and G. Zhixiong, "Xiaoaiping injection combining with NP regiment in the treatment of 56 patients with advanced lung cancer," Journal of Basic and Clinical Oncology, vol. 22, pp. 4748, 2009 (Chinese).
[29] W. Li, R. Song, X. Fang et al., "SBF-1, a synthetic steroidal glycoside, inhibits melanoma growth and metastasis through blocking interaction between PDK1 and AKT3," Biochemical Pharmacology, vol. 84, no. 2, pp. 172-181, 2012.

[30] S. V. Novitskiy, I. Csiki, Y. Huang et al., "Anti-vascular endothelial growth factor treatment in combination with chemotherapy delays hematopoietic recovery due to decreased proliferation of bone marrow hematopoietic progenitor cells," Journal of Thoracic Oncology, vol. 5, no. 9, pp. 1410-1415, 2010.

[31] S. Song, C. Xiong, W. Lu, G. Ku, G. Huang, and C. Li, "Apoptosis imaging probe predicts early chemotherapy response in preclinical models: a comparative study with 18F-FDG PET,' Journal of Nuclear Medicine, vol. 54, no. 1, pp. 104-110, 2013.

[32] J. S. Kang, H. G. Kang, Y. I. Park et al., "Expression of epithelial cell adhesion molecule and proliferating cell nuclear antigen in diethylnitrosamine-induced hepatocarcinogenesis in mice," Experimental and Therapeutic Medicine, vol. 5, no. 1, pp. 138142, 2013.

[33] Y. Lazrek, O. Dubreuil, V. Garambois et al., "Anti-HER3 domain 1 and 3 antibodies reduce tumor growth by hindering HER2/HER3 dimerization and AKT-induced MDM2, XIAP, and FoxO1 phosphorylation," Neoplasia, vol. 15, no. 3, pp. 335347, 2013.

[34] A. Gopalan, W. Yu, B. G. Sanders, and K. Kline, "Simvastatin inhibition of mevalonate pathway induces apoptosis in human breast cancer cells via activation of JNK/CHOP/DR5 signaling pathway," Cancer Letters, vol. 329, no. 1, pp. 9-16, 2013.

[35] C. B. Ryder, K. McColl, and C. W. Distelhorst, "Acidosis blocks CCAAT/enhancer-binding protein homologous protein (CHOP)- and c-Jun-mediated induction of p53-upregulated mediator of apoptosis (PUMA) during amino acid starvation," Biochemical and Biophysical Research Communications, vol. 430, no. 4, pp. 1283-1288, 2013.

[36] A. Boissonnas, F. Licata, L. Poupel et al., "CD8 ${ }^{+}$tumorinfiltrating $\mathrm{T}$ cells are trapped in the tumor-dendritic cell network," Neoplasia, vol. 15, no. 1, pp. 85-94, 2013.

[37] M. Kremer, Y. Suezer, A. Volz et al., "Critical role of perforindependent $\mathrm{CD} 8^{+} \mathrm{T}$ cell immunity for rapid protective vaccination in a murine model for human smallpox," PLoS Pathogens, vol. 8, no. 3, Article ID e1002557, 2012.

[38] J. C. Silverio, I. R. Pereira, C. C. Mda et al., "CD8 ${ }^{+}$T-cells expressing interferon gamma or perforin play antagonistic roles in heart injury in experimental Trypanosoma cruzi-elicited cardiomyopathy," PLoS Pathogens, vol. 8, no. 4, Article ID e1002645, 2012. 


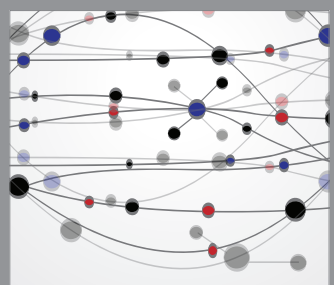

The Scientific World Journal
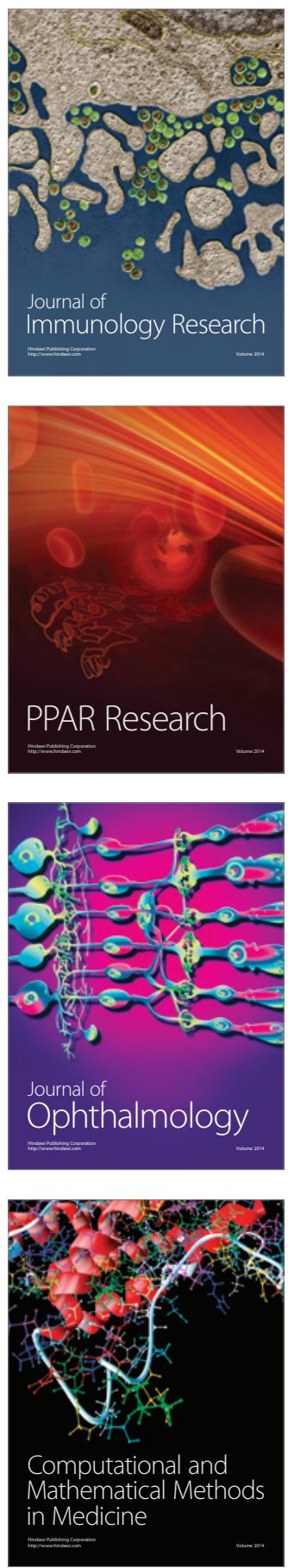

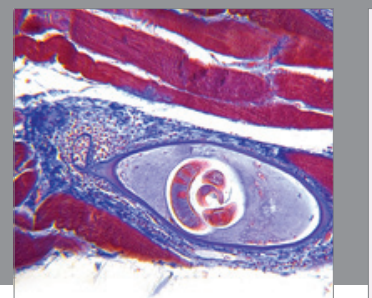

Gastroenterology

Research and Practice
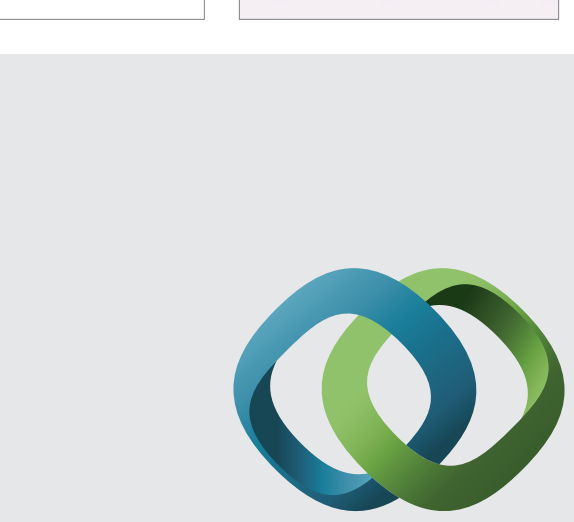

\section{Hindawi}

Submit your manuscripts at

http://www.hindawi.com
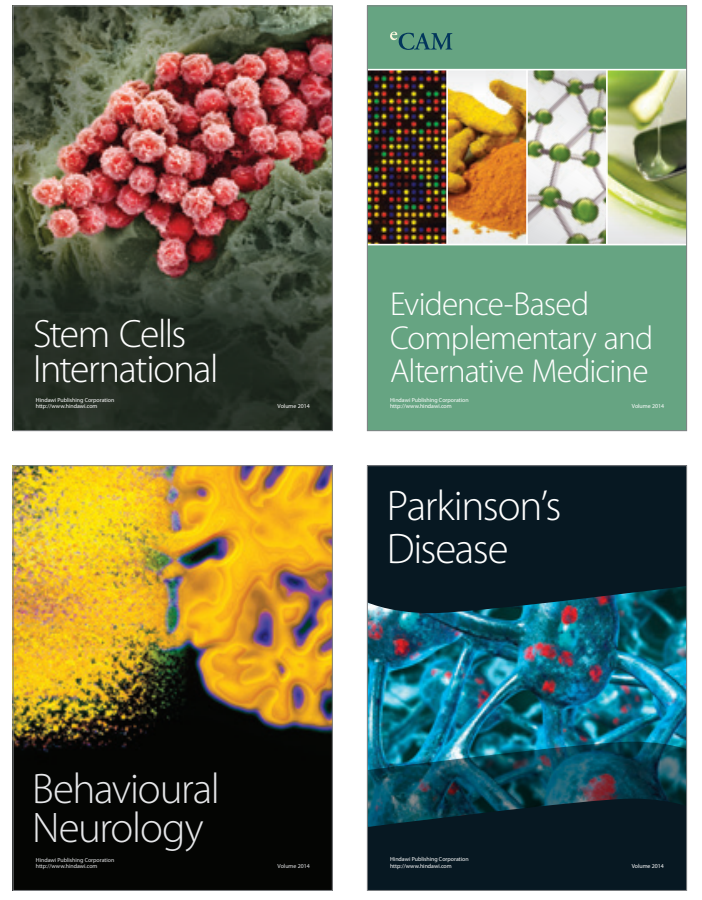
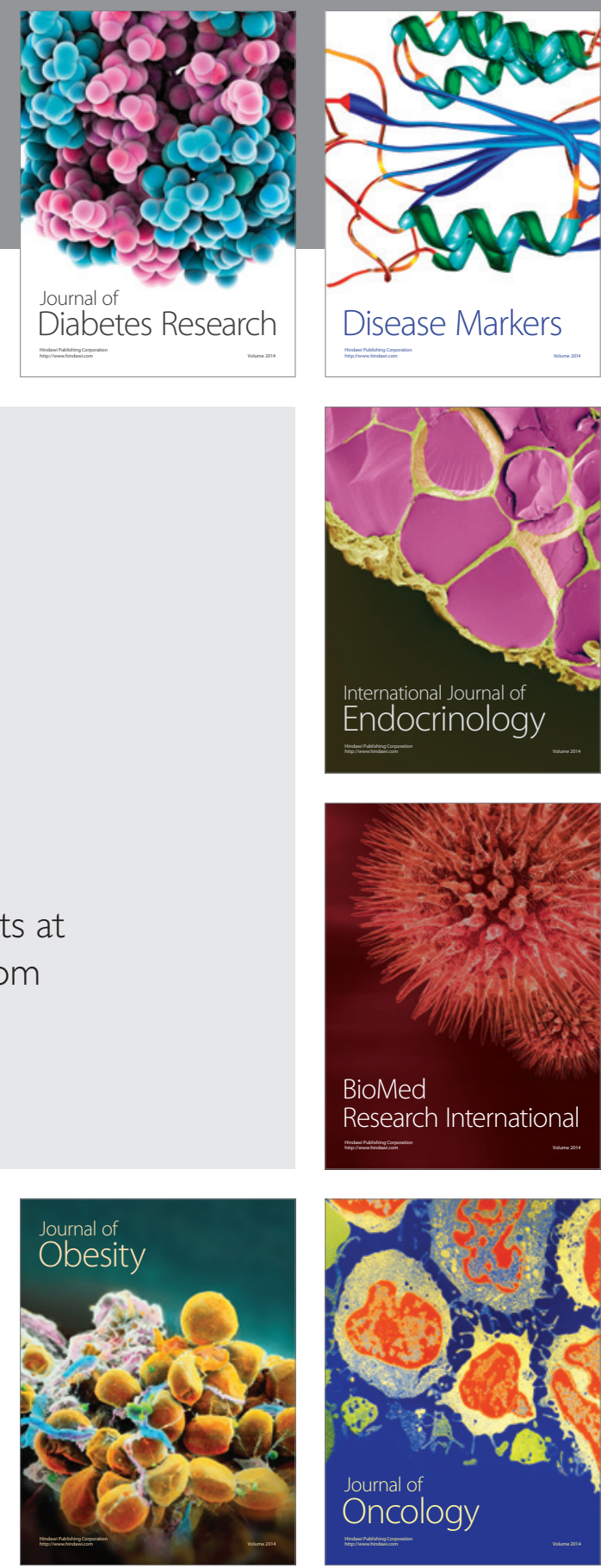

Disease Markers
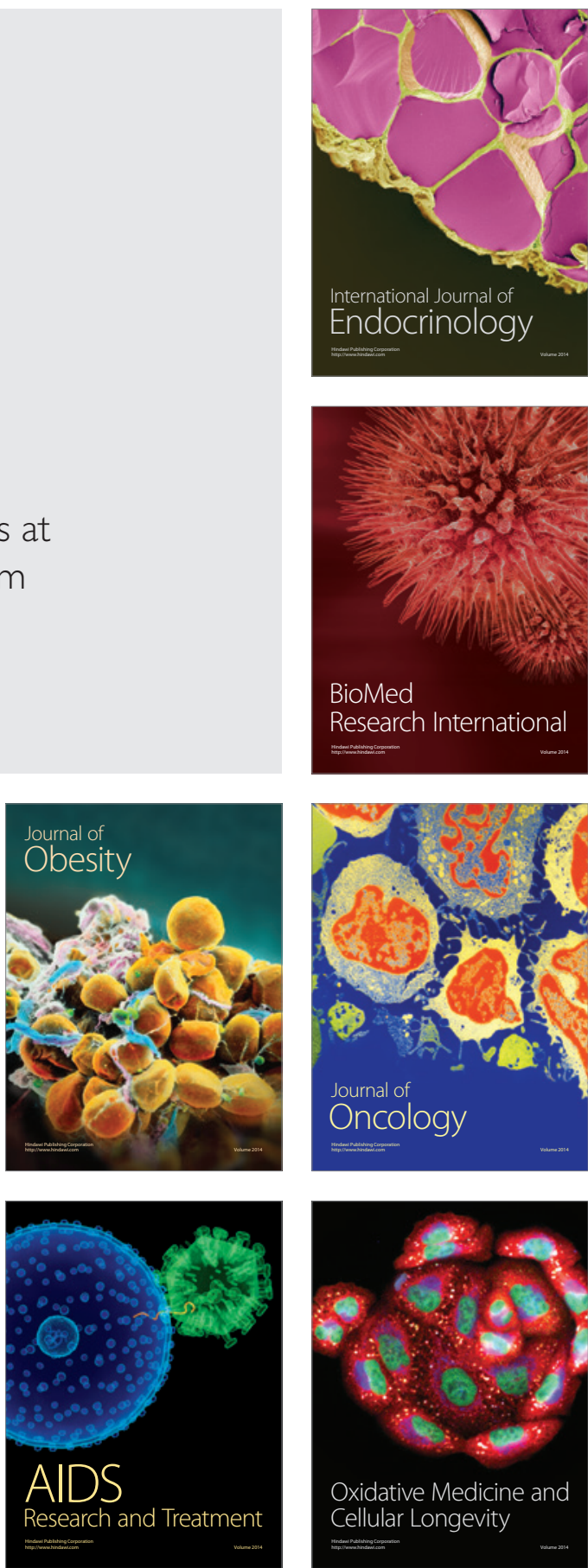